\title{
Application of $\boldsymbol{n}$-Dodecyltrimethylammonium Chloride for the Oxidation of Intermetallic Phases
}

\author{
Bodo Böhme, Stefan Hoffmann, Michael Baitinger, and Yuri Grin \\ Max-Planck-Institut für Chemische Physik fester Stoffe, Nöthnitzer Straße 40, 01187 Dresden, \\ Germany \\ Reprint requests to B. Böhme. Fax: +49 351464640 02. E-mail: bodo.boehme@cpfs.mpg.de
}

Z. Naturforsch. 2011, 66b, 230 -238; received November 6, 2010

\begin{abstract}
The thermal decomposition products of ionic liquids based on $n$-dodecyltrimethylammonium chloride (DTAC) were used for the preparation of the metastable allotrope $\mathrm{Ge}(c F 136)$ by oxidation of $\mathrm{Na}_{12} \mathrm{Ge}_{17}$ in gas-solid reactions. This method of preparation provides a promising low-temperature route for the synthesis of intermetallic phases and elemental modifications. In order to explore the reaction mechanism, we investigated the thermal decomposition of DTAC as well as of the ionic liquids DTAC/ $\mathrm{MgCl}_{2}$ and DTAC/AlCl 3 by in-situ mass spectrometry and by powder X-ray diffraction. The results have revealed $\mathrm{HCl}, \mathrm{CH}_{3} \mathrm{Cl}$ and 1-chlorododecane to act as oxidizing agents in the gas-solid redox reactions.
\end{abstract}

Key words: DTAC, Ionic Liquid, Oxidation, $\mathrm{Ge}(c F 136), \mathrm{Ge}(h R 8)$

\section{Introduction}

Intermetallic phases are usually obtained from the melt or by diffusion-controlled reactions in the solid state at sufficiently high reaction temperatures. However, phases with low temperature stability or metastable phases are hardly accessible this way. A more promising method for low-temperature syntheses is the controlled oxidation of intermetallic precursors by reactive agents. By this approach, a metastable germanium allotrope $\mathrm{Ge}(c F 136)$ with clathrate-II structure was obtained when heating the dispersion of $\mathrm{Na}_{12} \mathrm{Ge}_{17}$ in the ionic liquid (IL) DTAC/AlCl 3 [1]. The metastable clathrate-II $\mathrm{K}_{8.6} \mathrm{Ge}_{136}$ was similarly prepared from $\mathrm{K}_{4} \mathrm{Ge}_{9}$ [2]. However, in addition to these crystalline products, considerable amounts of X-rayamorphous by-products were obtained. Recently, the problem of X-ray-amorphous by-products in the preparation of $\mathrm{Ge}(c F 136)$ has widely been overcome when only the gaseous thermal decomposition products of DTAC-based ILs were used for the oxidation of $\mathrm{Na}_{12} \mathrm{Ge}_{17}$ at $280{ }^{\circ} \mathrm{C}$ [3]. The resulting $\mathrm{Ge}(c F 136)$ product was particularly suited as a starting material for the high-pressure transformation into the allotrope $\mathrm{Ge}(h R 8)$ [4]. However, the improved preparative route to $\mathrm{Ge}(c F 136)$ and the nature of the gaseous oxidizing agents have not been reported yet. In this work we have investigated the thermal decomposition of DTAC and DTAC-based ionic liquids, and the gaseous products formed thereby. We explain how the decomposition products can be used for an optimized synthesis of the allotrope $\mathrm{Ge}(c F 136)$ via a gas-solid preparative route.

\section{Results and Discussion \\ Reaction of $\mathrm{Na}_{12} \mathrm{Ge}_{17}$ with the IL DTAC/AlCl 3}

The allotrope $\mathrm{Ge}(c F 136)$ was originally obtained by reacting a precursor of composition $\mathrm{NaGe}_{2.25}$ with the IL DTAC/AlCl 3 at $300{ }^{\circ} \mathrm{C}$ (Fig. 1a). The reaction was found to comprise a Hofmann elimination of the $n$-DTA ${ }^{+}$(n-dodecyltrimethylammonium) cations. The precursor was considered as a base for the abstraction of the acidic $\beta$ protons of $n$-DTA ${ }^{+}$, which are finally reduced to $\mathrm{H}_{2}$ during the reaction [1]. As the precursor consisted essentially of $\mathrm{Na}_{12} \mathrm{Ge}_{17}$ [5], the overall reaction to $\mathrm{Ge}(c F 136)$ (i.e. $\square_{24} \mathrm{Ge}_{136}$ ) can be written as:

$$
\begin{aligned}
& 8 \mathrm{Na}_{12} \mathrm{Ge}_{17}+96\left[\mathrm{C}_{12} \mathrm{H}_{25} \mathrm{~N}\left(\mathrm{CH}_{3}\right)_{3}\right] \mathrm{Cl} \longrightarrow \\
& \square_{24} \mathrm{Ge}_{136}+96 \mathrm{NaCl}+48 \mathrm{H}_{2} \\
& +96\left(\mathrm{C}_{10} \mathrm{H}_{21}\right) \mathrm{CH}=\mathrm{CH}_{2}+96 \mathrm{~N}\left(\mathrm{CH}_{3}\right)_{3}
\end{aligned}
$$

The liquid-solid reaction yields crystalline $\mathrm{Ge}(c F 136)$ and $\alpha$-Ge as a by-product. Moreover, the presence of $\mathrm{X}$-ray-amorphous phases is evidenced by a significant background in the powder X-ray diffraction patterns (Fig. 2a). 


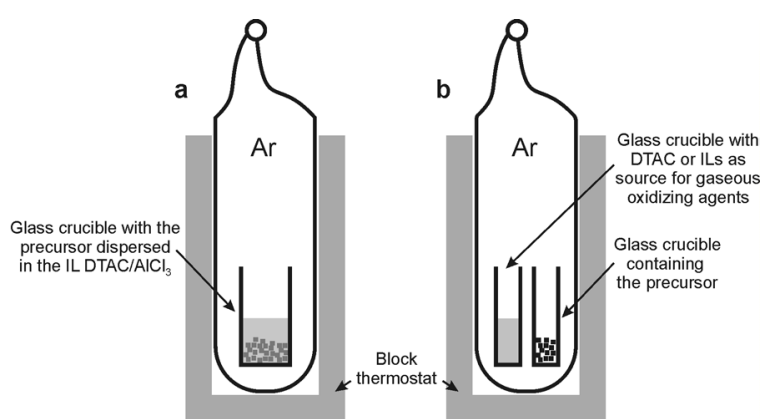

Fig. 1. Setup for the oxidation of intermetallic precursors (a) in a liquid-solid reaction with the IL DTAC/AlCl $3(1: 1$ molar ratio) and (b) in a gas-solid reaction with the gaseous decomposition products of the IL.

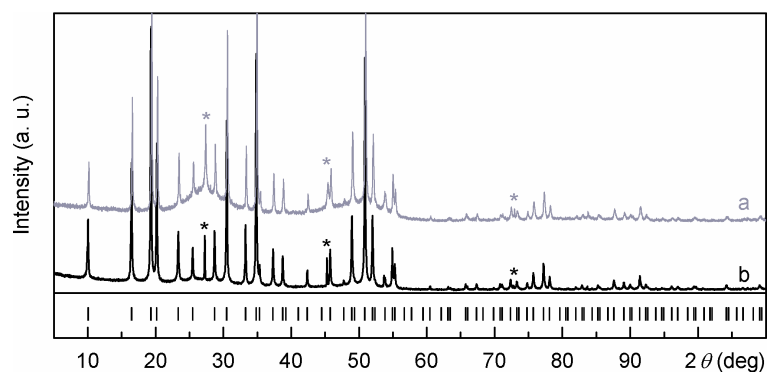

Fig. 2. Powder X-ray diffraction patterns of $\mathrm{Ge}(c F 136)$ products obtained by oxidation of $\mathrm{Na}_{12} \mathrm{Ge}_{17}$ after washing in (a) the liquid-solid reaction with the IL DTAC/AlCl $3(1: 1$ molar mixture) [1]; and in (b) the gas-solid reaction with gaseous decomposition products of DTAC/MgCl 2 (2:1 molar mixture) $[3,4]$. Asterisks mark reflection of $\alpha$-Ge.

The pure IL DTAC/AlCl 3 (1: 1 molar mixture) developed a significant vapor pressure at elevated temperatures due to its thermal decomposition. This led to the question, whether the gaseous decomposition products of the IL contribute to the oxidation of $\mathrm{Na}_{12} \mathrm{Ge}_{17}$ to $\mathrm{Ge}(c F 136)$. In order to react the precursor $\mathrm{Na}_{12} \mathrm{Ge}_{17}$ only with the gaseous decomposition products of the IL, a setup was chosen in which the IL and the precursor are arranged in a spatially separated fashion (Fig. 1b)* A gas-solid reaction of the gaseous decomposition products of the IL with $\mathrm{Na}_{12} \mathrm{Ge}_{17}$ yielded $\mathrm{Ge}(c F 136)$ as in the liquid-solid route, but the amount of X-ray-amorphous by-products was significantly reduced. The reaction could also be performed with DTAC/ $\mathrm{MgCl}_{2}$ and with pure DTAC as sources for

\footnotetext{
* A similar setup has already successfully been used for the oxidation of the silicides $\mathrm{Na}_{4} \mathrm{Si}_{4}, \mathrm{~K}_{4} \mathrm{Si}_{4}$ and $\mathrm{Na}_{2} \mathrm{BaSi}_{4}$ with gaseous $\mathrm{HCl}$ to clathrate-I phases $\mathrm{Na}_{6.2} \mathrm{Si}_{46}, \mathrm{~K}_{7.0} \mathrm{Si}_{46}$, and $\mathrm{Na}_{2} \mathrm{Ba}_{6} \mathrm{Si}_{46}$ [6]. $\mathrm{Na}_{12} \mathrm{Ge}_{17}$ was obtained by heating the elements in sealed Ta ampoules to $1100{ }^{\circ} \mathrm{C}[3]$
}

gaseous oxidizing agents. The powder X-ray diffraction pattern of a $\mathrm{Ge}(c F 136)$ product obtained under optimized conditions using DTAC/ $\mathrm{MgCl}_{2}(2: 1$ molar ratio, $280^{\circ} \mathrm{C}, 300 \mathrm{~h}$ ) is shown in Fig. 2 b. Because $\mathrm{NaCl}$ was found in all products of the gas-solid reactions, the gas phase must have contained chlorides which acted as oxidizing agents. $\mathrm{NaCl}$ was easily separated from $\mathrm{Ge}(c F 136)$ by washing with water.

Formation of DTAC-based ionic liquids as sources of oxidizing agents

Upon mixing DTAC with $\mathrm{AlCl}_{3}$, a clear and slightly yellowish melt was formed. A slight temperature increase of the mixture indicated an exothermic reaction. Upon cooling to r.t., the melt solidified gradually. The melting point of the $1: 1$ molar mixture was estimated to be $50{ }^{\circ} \mathrm{C}$. The melt of DTAC/AlCl 3 contains quaternary ammonium cations $n$-DTA ${ }^{+}$and $\left[\mathrm{AlCl}_{4}\right]^{-}$anions in equilibrium with $\left[\mathrm{Al}_{2} \mathrm{Cl}_{7}\right]^{-}$and $\mathrm{Cl}^{-}$(Eqs. 2, 3) [7].

$$
\begin{aligned}
& \mathrm{DTAC}+\mathrm{AlCl}_{3} \longrightarrow n-\mathrm{DTA}^{+}\left[\mathrm{AlCl}_{4}\right]^{-} \\
& {\left[\mathrm{Al}_{2} \mathrm{Cl}_{7}\right]^{-} \underset{+\mathrm{AlCl}_{3}}{\stackrel{-\mathrm{AlCl}_{3}}{\rightleftarrows}}\left[\mathrm{AlCl}_{4}\right]^{-} \rightleftarrows \mathrm{AlCl}_{3}+\mathrm{Cl}^{-}}
\end{aligned}
$$

The $2: 1$ molar mixture of DTAC/MgCl 2 was found to have a distinctly higher melting point of approximately $150{ }^{\circ} \mathrm{C}$. A colorless and clear IL was formed above this temperature. In the IL DTAC/ $\mathrm{MgCl}_{2}$, chloro complexes $\left[\mathrm{MgCl}_{4}\right]^{2-}$ or $\left[\mathrm{MgCl}_{3}\right]^{-}$should exist as well, but their stability is expected to be lower than that of $\left[\mathrm{AlCl}_{4}\right]^{-}$due to the reduced Lewis acidity of $\mathrm{Mg}^{2+}$ compared with $\mathrm{Al}^{3+}$. Therefore, the $\mathrm{Cl}^{-}$concentration in the melt should be higher in the neutral IL DTAC/ $\mathrm{MgCl}_{2}(2: 1)$ than in the neutral IL $\mathrm{DTAC}_{\mathrm{AlCl}}$ (1:1). Among the anions in the melt, $\mathrm{Cl}^{-}$is both the most nucleophilic and the most basic species, which is important for the decomposition reactions discussed below.

\section{The thermal decomposition of the IL DTAC/AlCl 3 investigated by in-situ mass spectrometry}

Thermal decomposition of quaternary ammonium ions has been investigated for a variety of salts and solvents [8-13]. In the case of DTAC, thermal decomposition has been studied in organic solvents [14] and at the surface of clay minerals [15]. From these results, different reaction paths can be expected to occur for the $n$-DTA ${ }^{+}$ions upon heating a DTAC-based system. The 

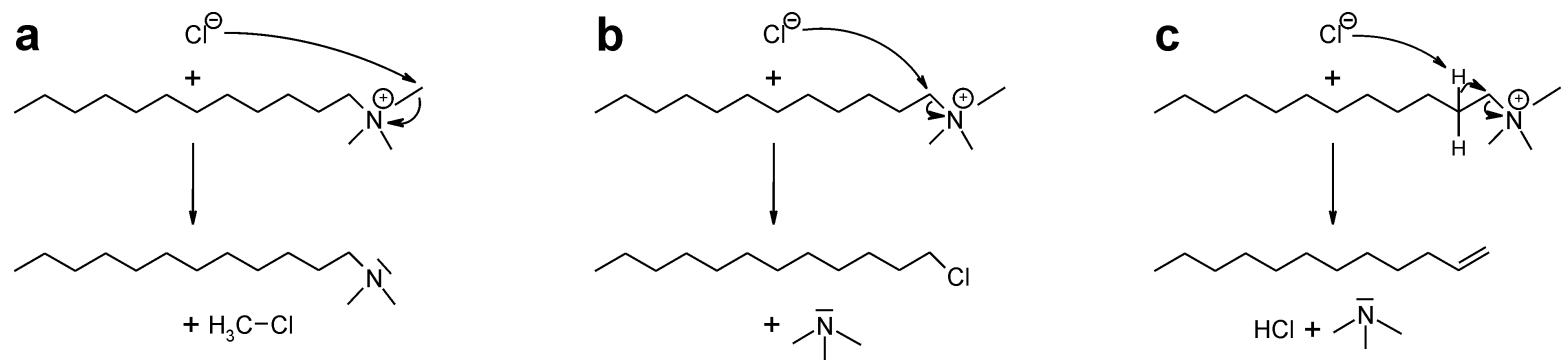

Fig. 3. Reaction paths of the $\mathrm{Cl}^{-}$-induced thermal decomposition of $n$-DTA ${ }^{+}$ions: (a), (b) nucleophilic substitutions with $\mathrm{S}_{N} 2$ mechanism and (c) Hofmann elimination with E2 mechanism.

decomposition is initiated by the attack of $\mathrm{Cl}^{-}$anions at different positions of the $n$-DTA ${ }^{+}$cations (Fig. 3 ).

A nucleophilic attack $\left(\mathrm{S}_{N} 2\right.$ mechanism) of $\mathrm{Cl}^{-}$on an $\alpha$-C atom of the $N$-methyl groups leads to the formation of $\mathrm{CH}_{3} \mathrm{Cl}$ and $\mathrm{N}, \mathrm{N}$-dimethyldodecylamine (Fig. 3a), while an attack on the $\alpha$-C atom of the dodecyl group yields 1-chlorododecane and $\mathrm{N}\left(\mathrm{CH}_{3}\right)_{3}$ (Fig. 3b). If the $\mathrm{Cl}^{-}$anion acts as a base, it favorably attacks the acidic protons in $\beta$ position of the dodecyl chain. This initiates a Hofmann elimination (E2 mechanism), yielding 1-dodecene, $\mathrm{N}\left(\mathrm{CH}_{3}\right)_{3}$ and $\mathrm{HCl}$ (Fig. 3c).

Upon heating the IL DTAC/AlCl 3 at the constant temperature of $280{ }^{\circ} \mathrm{C}$, characteristic products for all three reaction paths were found in the gas phase by TG-MS (Fig. 4). The decomposition started already at $\approx 160{ }^{\circ} \mathrm{C}$ as indicated by a significant mass loss and by the detection of gaseous decomposition products (Fig. 4). At $280{ }^{\circ} \mathrm{C}$, the following decomposition products were directly identified by their molecular ion peaks: $\mathrm{CH}_{3} \mathrm{Cl}$ (main contribution for the signal $\mathrm{m} / z=50 / 52$ ) and $N, N$-dimethyldodecylamine $(m / z=213)$, indicative of the mechanism in Fig. 3a, 1-chlorododecane $(m / z=204 / 206)$, indicative of the mechanism in Fig. 3b, and 1-dodecene (main contribution for the signal $\mathrm{m} / \mathrm{z}=168$ ), indicative of the mechanism in Fig. 3c. Characteristic fragmention peaks were identified as well. In the case of 1chlorododecane, the molecular ion peak became very small in intensity with progressing reaction time, but characteristic fragment-ion peaks (main contributions of the signals $m / z=105 / 107$ and $m / z=91 / 93$ ) remained visible during the whole experiment. For the other compounds mentioned above the molecular-ion peaks also remained clearly visible.

The identification of molecules with low molecular mass is often hampered by the overlap of the respective molecular ion peaks with signals of fragment ions.
In our case the unambiguous identification of $\mathrm{CH}_{3} \mathrm{Cl}$ (Fig. 3a) was successful because no significant signal overlap at $m / z=50 / 52$ occurred. For $\mathrm{N}\left(\mathrm{CH}_{3}\right)_{3}$, which is an expected product of the mechanisms in Figs. $3 \mathrm{~b}$ and $\mathrm{c}$, the direct assignment of the molecular ion peak $(m / z=59)$ was not possible because the radical cation $\left.\left[\mathrm{N}_{(\mathrm{CH}}\right)_{3}\right]^{+}$is also a characteristic fragment of $N, N$-dimethyldodecylamine. In the experimental spectra an almost time-constant ratio of $I(59) / I(213) \approx 4$ was detected. However, the fragmentation of $N, N$-dimethyldodecylamine should only lead to an intensity ratio of $I(59) / I(213)=1.85$ [16]. The observed distinctly higher value indicates the presence of $\mathrm{N}\left(\mathrm{CH}_{3}\right)_{3}$ in the gas mixture. The detection of $\mathrm{HCl}$, which is an expected product of the Hofmann elimination (Fig. 3c), is hampered by the high Ar content in the experimental setup. Even the argon isotopes ${ }^{36} \mathrm{Ar}$ and ${ }^{38} \mathrm{Ar}$ with low natural abundance produced strong ion peaks.

The markedly higher intensity of the $\mathrm{CH}_{3} \mathrm{Cl}$ molecular ion peaks compared to the most intense peaks of 1-chlorododecane confirms the expectation [8-10] that the nucleophilic substitution by the $\mathrm{Cl}^{-}$ions proceeds on the more electrophilic $N$-methyl $\alpha$-C atoms of $n$ $\mathrm{DTA}^{+}$(Fig. 3a), rather than on the $\alpha$-C atoms of the dodecyl chain (Fig. 3b). However, a quantitative interpretation of the signal intensities in the mass spectra would require detailed knowledge about volatility and ion yield of the different compounds [12].

Signals at $m / z=17 / 18$ observed during the heating process disappeared when the temperature of $280{ }^{\circ} \mathrm{C}$ was reached. We assign these peaks to layers of water adsorbed on the apparatus.

\section{Thermal decomposition in closed ampoules}

The preparation of $\mathrm{Ge}(c F 136)$ by oxidation of $\mathrm{Na}_{12} \mathrm{Ge}_{17}$ with DTAC-based ILs was performed in sealed glass ampoules (Fig. 1b) [3,4]. Temperature and 


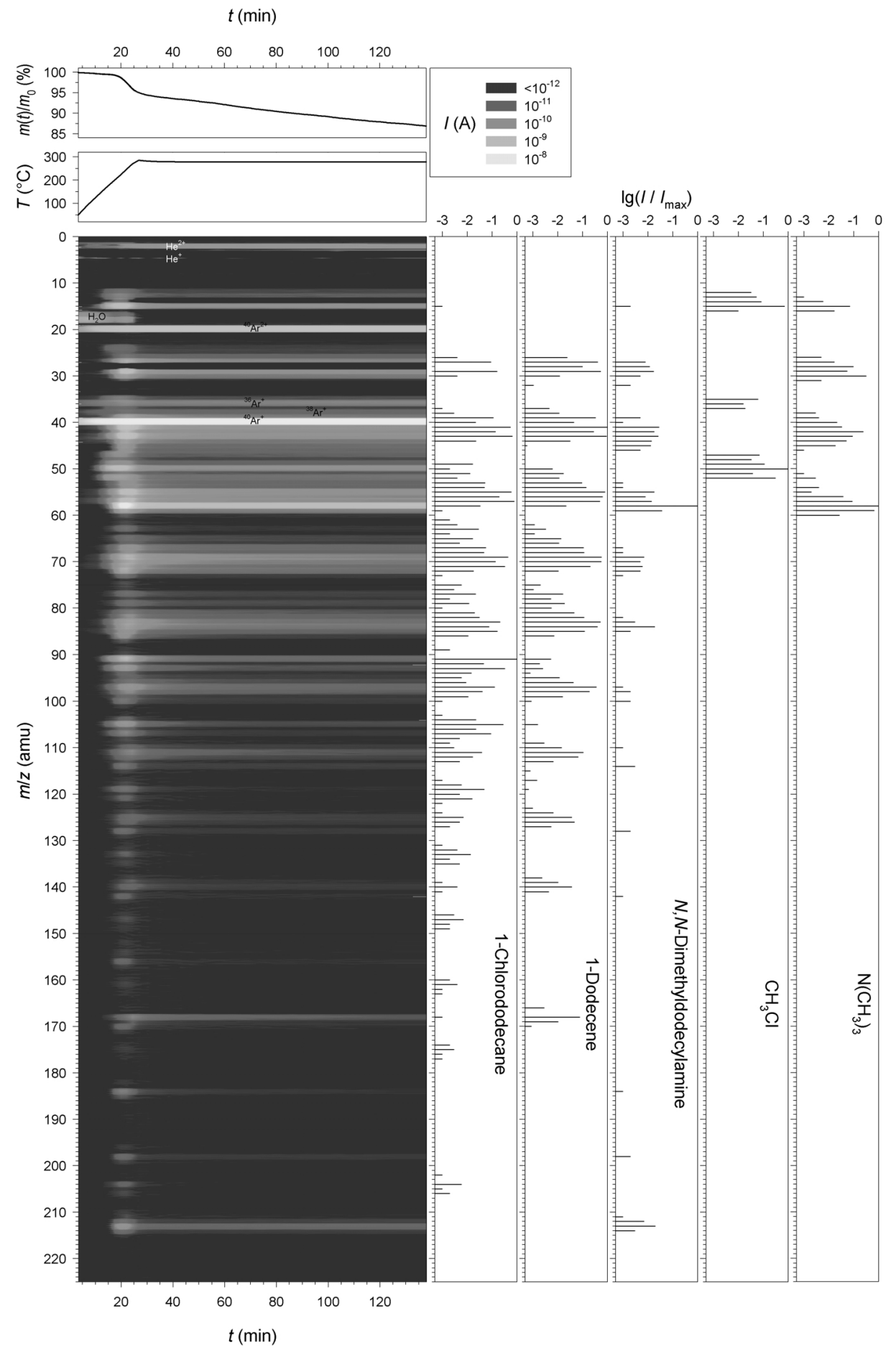

Fig. 4. Time-resolved combined thermogravimetric and mass spectrometric investigation of the decomposition of the IL DTAC/AlCl 3 at $280^{\circ} \mathrm{C}$ : sample mass normalized to the initial mass of the specimen (top), sample temperature (middle), mass spectra with ion current expressed in grey scale (bottom). Reference mass spectra [16] of 1-chlorododecane, 1-dodecene, $N, N$-dimethyldodecylamine, $\mathrm{CH}_{3} \mathrm{Cl}$ and $\mathrm{N}\left(\mathrm{CH}_{3}\right)_{3}$ are plotted on the right. 
Table 1. Thermal decomposition of DTAC-based systems at $280{ }^{\circ} \mathrm{C}$ in sealed ampoules.

\begin{tabular}{lllll}
\hline System & $\begin{array}{l}\text { Relative } \\
\text { decomposition } \\
\text { rate }\end{array}$ & $\begin{array}{l}\text { Crystalline compounds identified in } \\
\text { the deposit at the top of the } \\
\text { ampoules }\end{array}$ & $\begin{array}{l}\text { Assigned gaseous products of the } \\
\text { thermal decomposition of } n \text {-DTA a }\end{array}$ & $\begin{array}{l}\text { Concluded major } \\
\text { decomposition } \\
\text { mechanism of } \\
n \text {-DTA }\end{array}$ \\
\hline DTAC & high & $\mathrm{N}\left(\mathrm{CH}_{3}\right)_{4} \mathrm{Cl}, \mathrm{DTAC}$ & $\begin{array}{l}\mathbf{C H}_{3} \mathbf{C l}, \mathbf{1} \text {-chlorododecane, } \\
\mathrm{N}\left(\mathrm{CH}_{3}\right)_{3}, N, N \text {-dimethyldodecylamine }\end{array}$ & Fig. 3a, b \\
DTAC/ $\mathrm{MgCl}_{2}(2: 1)$ & middle & $\mathrm{HN}\left(\mathrm{CH}_{3}\right)_{3} \mathrm{Cl}, \mathrm{N}\left(\mathrm{CH}_{3}\right)_{4} \mathrm{Cl}, \mathrm{NH}_{4} \mathrm{Cl}$ & $\begin{array}{l}\mathbf{H C l}, \mathbf{N}\left(\mathrm{CH}_{3}\right)_{3} \text {, possibly } \\
\mathbf{C H} \mathbf{H}_{3} \mathbf{C l},\left[\mathbf{H C l}, \mathbf{C H} \mathbf{C l}_{3}, \mathrm{NH}_{3}\right]\end{array}$ & Fig. 3c, a \\
DTAC/ $\mathrm{AlCl}_{3}(1: 1)$ & low & $\mathrm{NH}_{4} \mathrm{Cl}$ & $\mathbf{H C l}, \mathbf{N}\left(\mathrm{CH}_{3}\right)_{3},\left[\mathbf{H C l}, \mathbf{C H}_{3} \mathbf{C l}_{2} \mathrm{NH}_{3}\right]$ & Fig. 3c \\
\hline
\end{tabular}

${ }^{a}$ Oxidizing agents for intermetallic phases are printed bold. The products of secondary reactions during the decomposition are listed in brackets.

Table 2. Experimental findings during thermal decomposition of pure DTAC in sealed ampoules.

\begin{tabular}{lll}
\hline$T\left({ }^{\circ} \mathrm{C}\right) \quad t(\mathrm{~h})$ & Observations \\
\hline 185 & 24 & $\begin{array}{l}\text { Viscous colorless liquid and a colorless solid in the reaction crucible. } \\
\text { Small amounts of a colorless solid at the top of the ampoule. }\end{array}$ \\
140 & $\begin{array}{l}\text { Only a colorless solid residue remained in the reaction crucible. } \\
\text { The amount of colorless deposit at the top of the ampoule had increased. }\end{array}$ \\
$280 \quad 0.1 \quad \begin{array}{l}\text { Colorless smoke immediately rose from the reaction crucible. } \\
\text { Reflux of a colorless liquid. } \\
\text { Deposition of a colorless solid starts at the top of the ampoule. } \\
\text { Only a small amount of a colorless oily liquid remained in the reaction crucible. } \\
\text { Colorless solid at the top of the ampoule containing crystalline } \mathrm{N}\left(\mathrm{CH}_{3}\right)_{4} \mathrm{Cl} \text { and DTAC. The decomposition products had an } \\
\text { amine-like odor. } \\
\text { The solid is partially soluble in water forming a basic solution. }\end{array}$ \\
\end{tabular}

Table 3. Experimental findings during thermal decomposition of $\mathrm{DTAC} / \mathrm{MgCl}_{2}$ in sealed ampoules.

\begin{tabular}{|c|c|c|}
\hline$T\left({ }^{\circ} \mathrm{C}\right)$ & $t(\mathrm{~h})$ & Observations \\
\hline \multirow{4}{*}{185} & 0.1 & Colorless and clear liquid in the reaction crucible. \\
\hline & 05 & Colorless solid precipitated from the liquid in the reaction crucible. \\
\hline & 0.5 & Droplets of a colorless liquid started to form at the top of the ampoule, the amount of which increased with time. \\
\hline & 140 & Besides droplets, a colorless solid had formed at the top of the ampoule. \\
\hline \multirow{5}{*}{280} & 0.1 & $\begin{array}{l}\text { Colorless melt in the reaction crucible transforming into a solid within few minutes. } \\
\text { A colorless liquid started to reflux at the top of the ampoule. }\end{array}$ \\
\hline & 24 & A colorless solid started to deposit at the top of the ampoule. \\
\hline & & Strong reflux of colorless liquid. \\
\hline & 170 & $\begin{array}{l}\text { The amount of solid at the top of the ampoule had increased, containing crystalline } \mathrm{HN}\left(\mathrm{CH}_{3}\right)_{3} \mathrm{Cl} \text {, and smaller amounts of } \\
\mathrm{NH}_{4} \mathrm{Cl} \text { and } \mathrm{N}\left(\mathrm{CH}_{3}\right)_{4} \mathrm{Cl} \text {. }\end{array}$ \\
\hline & & $\begin{array}{l}\text { A solid remained inside the reaction crucible containing unidentified crystalline phases. A solution in water was weakly } \\
\text { basic. }\end{array}$ \\
\hline
\end{tabular}

pressure conditions in this setup differ from those in a Knudsen-like arrangement in TG-MS, which might influence the decomposition behavior of the $n$-DTA ${ }^{+}$ cations. Hence, we studied the thermal decomposition of DTAC/AlCl 3 , DTAC/MgCl 2 , and pure DTAC also in sealed ampoules at temperatures of $T=185{ }^{\circ} \mathrm{C}$ and $T=280{ }^{\circ} \mathrm{C}$ typically used for the oxidation reactions. Inside the sealed ampoules, the constituents of the gas phase could not be investigated in situ. However, the ex-situ identification of the decompo- sition products also allows to draw conclusions on the constituents of the gas phase and hence, on the decomposition mechanisms of the $n$-DTA ${ }^{+}$cations (Table 1).

When heated up to $185^{\circ} \mathrm{C}$, the IL samples were entirely liquid. Pure DTAC, which has been reported to decompose without melting at $237{ }^{\circ} \mathrm{C}$ [19], also partially reacted to a liquid phase within $24 \mathrm{~h}$. For all systems, decomposition products condensed at the top of the reaction ampoules on a time scale of several hours 
Table 4. Experimental findings during thermal decomposition of $\mathrm{DTAC} / \mathrm{AlCl}_{3}$ in sealed ampoules.

\begin{tabular}{|c|c|c|}
\hline$\overline{T\left({ }^{\circ} \mathrm{C}\right)}$ & $t(\mathrm{~h})$ & Observations \\
\hline \multirow{3}{*}{185} & 0.1 & Yellowish clear liquid in the reaction crucible turning to orange after several minutes. Gas bubbles were visible. \\
\hline & 1 & The liquid in the reaction crucible was dark red. The color persisted also after $24 \mathrm{~h}$. \\
\hline & 140 & $\begin{array}{l}\text { The liquid in the reaction crucible had turned to yellow. } \\
\text { Colorless droplets had condensed at the top of the ampoule. }\end{array}$ \\
\hline \multirow{6}{*}{280} & 0.1 & The initially yellowish melt turned to dark red within few minutes, and gas bubbles were observed. \\
\hline & 1 & $\begin{array}{l}\text { Reflux of colorless liquid increasing significantly within the next hours. The liquid in the reaction crucible had turned to } \\
\text { yellow. } \\
\text { After cooling down to r. t., the reflux collected as a colorless liquid outside the reaction crucible. } \\
\text { The liquid inside the reaction crucible solidified to an X-ray amorphous gel (Fig. 5a, b). }\end{array}$ \\
\hline & 72 & $\begin{array}{l}\text { The reflux collected outside of the reaction crucible was yellow and became brown after longer reaction times. } \\
\text { The liquid phase inside the reaction crucible darkened as well and solidified upon cooling. The residue showed reflections of } \\
\text { an unknown phase in PXRD (Fig. 5c). }\end{array}$ \\
\hline & 140 & $\begin{array}{l}\text { The amount of the liquid in the reaction crucible was decreased markedly. } \\
\text { A colorless solid started to deposit at the top of the ampoule. }\end{array}$ \\
\hline & 170 & $\begin{array}{l}\text { On cooling two immiscible liquids collected outside of the reaction crucible. The phase with the higher density was highly } \\
\text { viscous and dark brown, the one with lower density was yellow and clear. }\end{array}$ \\
\hline & 300 & $\begin{array}{l}\text { Only a small amount of a black solid residue remained in the reaction crucible. In PXRD it showed the same reflections as the } \\
\text { product in the reaction crucible after } 72 \mathrm{~h} \text {, but low in intensity. By hydrolysis with air moisture, } \mathrm{AlCl}_{3} \cdot 6 \mathrm{H}_{2} \mathrm{O} \text { was formed. } \\
\text { The colorless solid at the top of the ampoule contained } \mathrm{NH}_{4} \mathrm{Cl} \text { and unknown crystalline phases. }\end{array}$ \\
\hline
\end{tabular}

to days (Tables $2-4$ ). In case of DTAC/AlCl 3 , distinct color changes were also observed.

At $280{ }^{\circ} \mathrm{C}$, the decomposition rates strongly increased: For all systems, reflux of a liquid at the top of the ampoules was observed within a few minutes, along with rapid color changes in the case of DTAC/AlCl 3 . PXRD patterns of the cooled-down residues inside the reaction crucible differed from that of the solidified IL (Fig. 5). For pure DTAC, the substance almost completely disappeared from the reaction crucible within $1 \mathrm{~h}$.

The gaseous decomposition products of $n$-DTA ${ }^{+}$ were assigned on the basis of the identified crystalline deposition products at the top of the ampoules (Table 1). In the case of pure DTAC, the deposit contained $\mathrm{N}\left(\mathrm{CH}_{3}\right)_{4} \mathrm{Cl}$ and DTAC. The presence of $\mathrm{N}\left(\mathrm{CH}_{3}\right)_{4} \mathrm{Cl}$ proves $\mathrm{N}\left(\mathrm{CH}_{3}\right)_{3}$ and $\mathrm{CH}_{3} \mathrm{Cl}$ as constituents of the gas phase. $\mathrm{CH}_{3} \mathrm{Cl}$ should be formed in the nucleophilic substitution reaction according to Fig. 3a, $\mathrm{N}\left(\mathrm{CH}_{3}\right)_{3}$ in the nucleophilic substitution according to Fig. 3b. Hence, the gas phase should also contain $N, N$-dimethyldodecylamine and 1-chlorododecane. The presence of DTAC in the deposit consequently results from the reverse reactions. The presence of $\mathrm{N}\left(\mathrm{CH}_{3}\right)_{3}$ might also point to a Hofmann elimination of the $n$-DTA ${ }^{+}$cations (Fig. 3c). However, in this case $\mathrm{N}\left(\mathrm{CH}_{3}\right)_{3}$ and $\mathrm{HCl}$ should form $\mathrm{HN}\left(\mathrm{CH}_{3}\right)_{3} \mathrm{Cl}$, which was not detected in the deposit. The observed decomposition of $n$-DTA ${ }^{+}$cations via

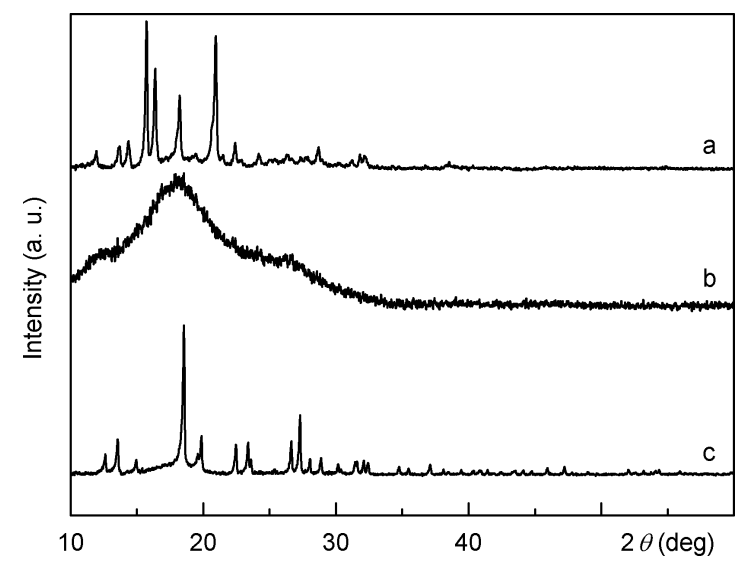

Fig. 5. PXRD patterns of the solidified ionic liquid DTAC/AlCl 3 (a) and of the residues in the reaction crucible after thermal treatment at $280{ }^{\circ} \mathrm{C}$ for $1 \mathrm{~h}$ (b) and $72 \mathrm{~h}$ (c). The patterns (b) and (c) possibly show the same product with different crystallinity.

nucleophilic substitution mechanisms is expected for the nucleophilic $\mathrm{Cl}^{-}$anions in pure DTAC [8-13].

For the decomposition of $\mathrm{MgCl}_{2}$ /DTAC, the deposit contained $\mathrm{HN}\left(\mathrm{CH}_{3}\right)_{3} \mathrm{Cl}$ as the main phase, as well as $\mathrm{NH}_{4} \mathrm{Cl}$ and $\mathrm{N}\left(\mathrm{CH}_{3}\right)_{4} \mathrm{Cl}$. The presence of $\mathrm{HN}\left(\mathrm{CH}_{3}\right)_{3} \mathrm{Cl}$ proves $\mathrm{HCl}$ and $\mathrm{N}\left(\mathrm{CH}_{3}\right)_{3}$ in the gas phase, which points to Hofmann elimination (Fig. 3c) as the dominating decomposition mechanism of $n$-DTA ${ }^{+}$. The occurrence of $\mathrm{NH}_{4} \mathrm{Cl}$ and $\mathrm{N}\left(\mathrm{CH}_{3}\right)_{4} \mathrm{Cl}$ can be attributed to the decomposition of $\mathrm{HN}\left(\mathrm{CH}_{3}\right)_{3} \mathrm{Cl}$. Thus, due to 


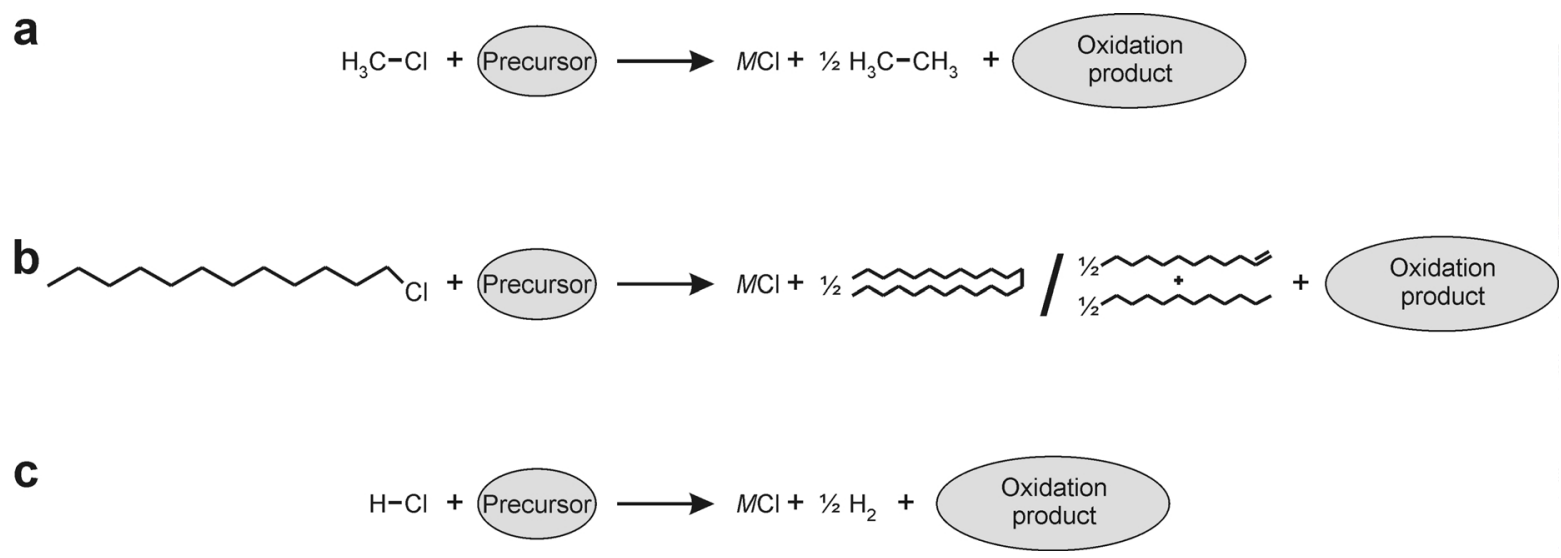

Fig. 6. Reaction schemes for the oxidation of intermetallic precursors with different oxidizing agents: (a) and (b) Wurtzanalogous and competing reactions of the organic chlorides, and (c) reaction of $\mathrm{HCl}$ under formation of $\mathrm{H}_{2}$.

secondary processes, the gas phase should additionally contain $\mathrm{CH}_{3} \mathrm{Cl}$, di- and monomethylamine [17], and $\mathrm{NH}_{3}$. $\mathrm{N}\left(\mathrm{CH}_{3}\right)_{4} \mathrm{Cl}$ might also be formed by the reaction of $\mathrm{N}\left(\mathrm{CH}_{3}\right)_{3}$ with $\mathrm{CH}_{3} \mathrm{Cl}$, which originates from the decomposition of $n$-DTA ${ }^{+}$according to the nucleophilic substitution mechanism depicted in Fig. 3a.

For the system DTAC/AlCl 3 , the deposit at the top of the ampoule was a multiphase product, in which only $\mathrm{NH}_{4} \mathrm{Cl}$ could be identified. The presence of $\mathrm{NH}_{4} \mathrm{Cl}$ might point to a Hofmann elimination of the $n$-DTA ${ }^{+}$cations to $\mathrm{HCl}, \mathrm{N}\left(\mathrm{CH}_{3}\right)_{3}$ and 1-dodecene (Fig. 3c). In a secondary process, $\mathrm{HCl}$ and $\mathrm{N}\left(\mathrm{CH}_{3}\right)_{3}$ should form $\mathrm{HN}\left(\mathrm{CH}_{3}\right)_{3} \mathrm{Cl}$, which finally decomposes to $\mathrm{NH}_{4} \mathrm{Cl}$ [17]. However, the presence of $\mathrm{AlCl}_{3}$ in the system complicates any conclusion on the decomposition mechanisms of $n$-DTA ${ }^{+} . \mathrm{AlCl}_{3}$ is known to catalyze proton- or methyl-transfer reactions, so that subsequent reactions of the original decomposition products of $n-\mathrm{DTA}^{+}$are enhanced. This might lead to an absence of the above-mentioned methylated ammonium chlorides expected to deposit (Fig. 3). Also, the occurrence of a black tar-like residue in the reaction crucible after long reaction times can be explained by the catalytic effect of $\mathrm{AlCl}_{3}$ in isomerization and polymerization reactions. The fragmentation of the $n$ $\mathrm{DTA}^{+}$cation and its decomposition products should lead to the formation of different amine complexes with $\mathrm{AlCl}_{3}$. Such Lewis acid-base complexes should be present both in the residues inside the reaction crucible and, if volatile [18], in the deposit at the top of the ampoule.

It is remarkable that no hints for $\mathrm{AlCl}_{3}$ were found in the gas phase in the TG-MS experiment described above. Because any deposit at the top of the ampoule was only observed after $140 \mathrm{~h}$ of heat treatment, we conclude that the evaporation of $\mathrm{Al}$ complexes starts only after longer heat treatment.

The reaction of gaseous decomposition products of DTAC with intermetallic phases

The gaseous decomposition products of $n$-DTA ${ }^{+}$ cations in DTAC or DTAC-based ILs explain the oxidation of intermetallic precursors such as $\mathrm{Na}_{12} \mathrm{Ge}_{17}$ in an experimental setup according to Fig. 1b. Upon heating, the oxidizing agents $\mathrm{HCl}, \mathrm{CH}_{3} \mathrm{Cl}$ and 1chlorododecane pass into the gas phase (Table 1). In the course of the redox reactions, protons of $\mathrm{HCl}$ are reduced to $\mathrm{H}_{2}$, and the organic chlorides can react in Wurtz-analogous reactions [8] or competing processes (Fig. 6a-c). The precursor is oxidized to the clathrate phase, and $\mathrm{NaCl}$ is formed as co-product. Well-crystallized $\mathrm{Ge}(c F 136)$ was favorably obtained in a reaction with the IL DTAC/MgCl $2(2: 1$ molar ratio) as gas source at $280{ }^{\circ} \mathrm{C}$ after $12 \mathrm{~d}$. By using DTAC/AlCl 3 under the same conditions, the reaction was incomplete [3]. Such differences cannot be explained by the kind of oxidizing agents formed from the respective DTAC-based system (Table 1), since they are all highly reactive towards $\mathrm{Na}_{12} \mathrm{Ge}_{17}$. In fact, the reaction rates are influenced by the total in-situ pressure of the oxidizing agents. Under the same conditions, the in-situ pressure of the oxidizing agents is determined by the decomposition rate of $n$-DTA ${ }^{+}$, which decreases in the order $r$ (DTAC) $>$ $r\left(\mathrm{DTAC} / \mathrm{MgCl}_{2}\right)>r\left(\mathrm{DTAC} / \mathrm{AlCl}_{3}\right)$. This result can 
be attributed to the concentration of free $\mathrm{Cl}^{-}$anions since all decomposition paths of $n$-DTA ${ }^{+}$follow second order mechanisms (Fig. 3). The decomposition rate of $n-\mathrm{DTA}^{+}$in the ILs is lower than the one of pure DTAC due to chloro complexes formed in the IL, diminishing the concentration of free $\mathrm{Cl}^{-}$ions. Comparing Lewis acidity, chloro complexes should be more stable with $\mathrm{AlCl}_{3}$ than with $\mathrm{MgCl}_{2}$, a fact which explains why DTAC/AlCl $\mathrm{Dl}_{3}$ decomposes more slowly than DTAC/ $\mathrm{MgCl}_{2}$.

Other experimental parameters such as reactor volume and temperature gradients can also influence the actual concentration of oxidizing gases. This is obviously the case, when decomposition products of DTAC deposit from the gas phase at the colder top of the reaction ampoule. Different kinds of deposits become especially important for longer reaction times.

\section{Conclusion}

The oxidation of $\mathrm{Na}_{12} \mathrm{Ge}_{17}$ to $\mathrm{Ge}(c F 136)$ by the use of DTAC-based ionic liquids in gas-solid reactions is explained: The oxidizing agents $\mathrm{HCl}, \mathrm{CH}_{3} \mathrm{Cl}$ and 1chlorododecane are formed by $\mathrm{Cl}^{-}$-induced thermal decomposition of $n$-DTA ${ }^{+}$cations via different reaction paths. The specific decomposition behavior of a DTAC-based system has a significant effect on the oxidation process. The knowledge of the thermal stability of the DTAC-based systems and their gaseous decomposition products allowed an optimized preparation of the allotrope $\mathrm{Ge}(c F 136)$. The direct use of the identified gaseous oxidizing agents will facilitate the application of this preparative method to other intermetallic compounds.

\section{Experimental Section}

\section{Preparation of the ionic liquids}

Before usage, the DTAC (Merck) was dried for $2 \mathrm{~d}$ under vacuum conditions at $25{ }^{\circ} \mathrm{C}$, until the pressure dropped below $5 \times 10^{-3}$ mbar. A mass loss of up to $4 \%$ was observed. $\mathrm{AlCl}_{3}$ (Merck, anhydrous powder, sublimed) was sublimed at $160{ }^{\circ} \mathrm{C}$ under $\mathrm{Ar}$ in a sealed glass ampoule. $\mathrm{MgCl}_{2}$ (Fluka, anhydrous purum, pure according to PXRD) was used as purchased. For the preparation of the ionic liquids, the respective components were mixed in an Ar-filled glove-box in glass crucibles (Duran). The IL DTAC/AlCl 3 was prepared at a molar ratio of $1: 1$, the IL DTAC/MgCl 2 at $2: 1$. Both compositions correspond to neutral ILs [7].

\section{In-situ investigation of the thermal decomposition of DTAC/AlCl 3 by TG-MS}

For an in-situ investigation by mass spectrometry the mixture of the components for the IL DTAC/AlCl 3 was homogenized at $T=100{ }^{\circ} \mathrm{C}$ under an argon atmosphere. Subsequently, the IL ( $m=11.17 \mathrm{mg}$ ) was transferred with a dry glass pipette to an $\mathrm{Al}_{2} \mathrm{O}_{3}$ crucible $\left(d=5 \mathrm{~mm}, V=85 \mathrm{~mm}^{3}\right)$. The crucible was covered by a cap with a small hole in order to resemble a Knudsen arrangement. The crucible was transferred under Ar to the TG-MS setup which was operated in an Ar-filled glove box. The measurement was carried out under a constant He stream $\left(50 \mathrm{~mL} \mathrm{~min}^{-1}\right)$. The reaction cell was heated in the oven of a thermobalance (Netzsch STA $409 \mathrm{CD}$ ) at a rate of $10 \mathrm{~K} \mathrm{~min}^{-1}$ up to $280{ }^{\circ} \mathrm{C}$ and kept at this temperature. The mass loss during the decomposition reaction was recorded. During the whole heat treatment, the gas phase was continuously directed to the ionization chamber of a quadrupole mass spectrometer (Pfeiffer Quadstar QMS 422 , electron impact ionization at $75 \mathrm{eV}$ ) by a skimmer located directly above the hole of the reaction cell. In order to remove the strong peaks of the purging gas, the mass spectra were corrected by subtracting a spectrum initially recorded at r. t. Nonetheless, $\mathrm{Ar}^{n+}$ and $\mathrm{He}^{2+}$ signals were detected during the whole measurement.

\section{Decomposition experiments in sealed ampoules}

The decomposition of DTAC was investigated on samples of $0.6 \mathrm{~g}(2.3 \mathrm{mmol})$; for the preparation of the ILs the respective amounts of $0.303 \mathrm{~g} \mathrm{AlCl}_{3}(2.3 \mathrm{mmol})$ or $0.108 \mathrm{~g}$ $\mathrm{MgCl}_{2}(1.15 \mathrm{mmol})$ were added to $0.6 \mathrm{~g}(2.3 \mathrm{mmol})$ of DTAC. Thermal treatment was performed in glass ampoules $\left(V \approx 50 \mathrm{~cm}^{3}, d_{\mathrm{i}}=26 \mathrm{~mm}, l \approx 90 \mathrm{~mm}\right)$ sealed under Ar. The ampoules were placed vertically in a block thermostat (Gebr. Liebisch GmbH, Bielefeld, Germany) kept at $185{ }^{\circ} \mathrm{C}$ or $280{ }^{\circ} \mathrm{C}$. In this arrangement, the top of the ampoules had a lower temperature than the bottom. The same setup was used for the oxidation of intermetallic compounds (Fig. 1). To terminate an experiment, the ampoule was removed from the thermostat and cooled in air to $r$. t. The products were further investigated under Ar atmosphere. The experimental observations are summarized in Tables 2-4.

Caution: During the reaction, high pressure develops in the ampoules and appropriate safety precautions must be taken.

\section{Powder X-ray diffraction}

Diffraction experiments on powdered samples of the decomposition products of DTAC and the ILs were performed in air using a Huber G670 image plate Guinier camera (transmission setup, $\mathrm{Cu} K \alpha_{1}$ radiation, $\lambda=1.540598 \AA$, Ge (111) monochromator, $5^{\circ} \leq 2 \theta \leq 100^{\circ}, \Delta 2 \theta=0.005^{\circ}$ ). 
To prevent hydrolysis, the samples were fixed under Ar atmosphere between two polyimide foils $(7.5 \mu \mathrm{m}$, Kapton, Chemplex) on the sample holder. Data for an optimized evaluation of the background intensity originating from X-ray amorphous constituents were collected with a Stoe STADI P diffractometer using a zero-background sample holder (Bragg-Brentano geometry, $\mathrm{Cu} K \alpha_{1}$ radiation, $\lambda=1.540598 \AA$, Ge (111) monochromator, $5 \leq 2 \theta \leq 120^{\circ}$, $\left.\Delta 2 \theta=0.02^{\circ}\right)$.

\section{Acknowledgements}

We sincerely thank S. Scharsach for performing the TG-MS measurement, the Kompetenzgruppe Struktur for PXRD patterns, and Dr. J. Hunger for the discussion of the manuscript. B. B. and Y. G. gratefully acknowledge funding by the European Union and the Free State of Saxony (SAB project 13853/2379), M. B. and Y. G. gratefully acknowledge financial support by the Deutsche Forschungsgemeinschaft (SPP 1415, "Kristalline Nichtgleichgewichtsphasen (KNG) - Präparation, Charakterisierung und in-situ-Untersuchung der Bildungsmechanismen“).
[1] A. M. Guloy, R. Ramlau, Z. Tang, W. Schnelle, M. Baitinger, Y. Grin, Nature 2006, 443, 320 - 323.

[2] A. M. Guloy, Z. Tang, R. Ramlau, B. Böhme, M. Baitinger, Y. Grin, Eur. J. Inorg. Chem. 2009, $2455-$ 2458.

[3] B. Böhme, Neue Präparationswege für intermetallische Verbindungen, Logos, Berlin, 2010.

[4] U. Schwarz, A. Wosylus, B. Böhme, M. Baitinger, M. Hanfland, Y. Grin, Angew. Chem. 2008, 120, 6895 6898; Angew. Chem. Int. Ed. 2008, 47, 6790-6793.

[5] W. Carrillo-Cabrera, R. Cardoso Gil, M. Somer, Ö. Persil, H. G. von Schnering, Z. Anorg. Allg. Chem. 2003, $629,601-608$.

[6] B. Böhme, A. Guloy, Z. Tang, W. Schnelle, U. Burkhardt, M. Baitinger, Y. Grin, J. Am. Chem. Soc. 2007, 129, 5348-5349; B. Böhme, U. Aydemir, A. Ormeci, W. Schnelle, M. Baitinger, Y. Grin, Sci. Technol. Adv. Mater. 2007, 8, 410-415.

[7] C. M. Gordon, M. J. Muldoon in Ionic Liquids in Synthesis (Eds.: P. Wasserscheid, T. Welton), Wiley-VCH, Weinheim, 2003, chapter 2.1, p. 14.

[8] H. R. Christen, F. Vögtle, Organische Chemie - Von den Grundlagen zur Forschung, Band I, Otto Salle, Frankfurt am Main; Sauerländer, Aarau, 1992.

[9] A. Cope, E. R. Trumbull in Organic Reactions, Vol. 11 (Ed.-in-chief: A Cope), John Wiley\&Sons Inc., New York, London, 1960.

[10] E. D. Hughes, C. K. Ingold, C. S. Patel, J. Chem. Soc. 1933, $526-530$.

[11] W. Hanhart, C. K. Ingold, J. Chem. Soc. 1927, $997-$ 1020 .
[12] M. Hesse, H. Meier, B. Zeeh, Spektroskopische Methoden in der organischen Chemie, Georg Thieme Verlag, Stuttgart, 2005.

[13] M. Hesse, W. Vetter, H. Schmid, Helv. Chim. Acta 1965, 48, 674-689; M. Hesse, Fortschr. Chem. Forsch. 1967, 8, 608-651; R. E. Verrall, J. A. Burns, Can. J. Chem. 1974, 52, 3438 -3443; H. J. Veith, Mass Spectrom. Rev. 1983, 2, 419-446.

[14] S. Takano, C. Takasaki, K. Kunihiro, M. Yamanaka, J. Am. Oil. Chem. Soc. 1977, 54, 139- 143.

[15] W. Xie, Z. Gao, W. -P. Pan, D. Hunter, A. Singh, R. Vaia, Chem. Mater. 2001, 13, 2979-2990; W. Xie, Z. Gao, K. Liu, W.-P. Pan, R. Vaia, D. Hunter, A. Singh, Thermochim. Acta 2001, 367-368; ibid. 339-350.

[16] S.E. Stein in NIST Chemistry WebBook, NIST Standard Reference Database Number 69 (Eds.: P. J. Linstrom, W. G. Mallard), National Institute of Standards and Technology, Gaithersburg MD, 2010, http://webbook.nist.gov; N. Wasada in SDBSWeb, National Institute of Advanced Industrial Science and Technology 2009, http://riodb01.ibase.aist.go.jp/sdbs/.

[17] C. Vincent, C.R. Hebd. Acad. Sci. 1877, T84, $1139-$ 1141; C. Vincent, J. Chem. Soc. Abstr. 1878, 34, 4004011; C. Vincent, C.R. Hebd. Acad. Sci. 1877, T85, 667-671; C. Vincent, J. Chem. Soc. Abstr. 1878, 34, 25.

[18] H. Jacobs, B. Nöcker, Z. Anorg. Allg. Chem. 1993, 619, $73-76$; H. Jacobs, B. Nöcker, Z. Anorg. Allg. Chem. 1992, 614, 25-29.

[19] DTAC Safety Data Sheet, Merck KGaA, Darmstadt, 2004. 